\title{
Perancangan Sistem Informasi Akademik Sekolah Berbasis Web (Studi Kasus SMPK Harapan Denpasar)
}

\author{
Agus Tommy Adi Prawira Kusuma \\ Prodi Sistem Informasi, Universitas Dhyana Pura, Badung, Bali \\ agustommyadi@yahoo.com
}

\begin{abstract}
Management Information Systems Academic School is an information system whose purpose is to help schools overcome problems related to data processing in schools academic. Reporting can be done easily because it can be handled by the system. The system is built with web-based technology, the MySQL database server, and use the C \# programming language used in the ASP.NET framework.

This system can be accessed simultaneously by multiple users through a network of local schools, where every user in the system has a different authority are set according to user groups so that the system can restrict users to access a particular page. This system makes the calculation of grades were calculated manually by using the formula: (Task x 15\%) + (exam $1 \times 25 \%)+$ $($ Exam $2 \times 25 \%)+($ Final Exams x 35\%)

School Academic Management Information System designed in this study, is able to handle the data of new admissions, class divisions, subjects, student grades, attendance of students and preparing reports on the results of the selection of new students, student identity data, alumni data, the data of parents, student attendance, class division result, the value of the daily tests and assignments, the value of general tests and exams, grades for each subject, grades each student and student statistical data.
\end{abstract}

Keywords : information systems, academic school, asp.net, web applications.

\begin{abstract}
ABSTRAK
Sistem Informasi Manajemen Akademik Sekolah merupakan system informasi yang bertujuan untuk membantu sekolah dalam mengatasi permasalahan-permasalahan yang dihadapi dalam melakukan pengolahan data yang berkaitan dengan akademik sekolah. Sistem dibangun dengan teknologi berbasis web, database server MySQL, dan menggunakan bahasa pemrograman C\# yang digunakan dalam framework ASP.NET.

Sistem ini dapat diakses secara bersamaan oleh beberapa pengguna melalui jaringan local sekolah, dimana setiap pengguna dalam system ini memiliki otoritas yang berbeda-beda yang diatur sesuai dengan group user sehingga sistem dapat membatasi pengguna untuk mengakses halaman tertentu. Sistem ini membuat perhitungan nilai rapor yang dihitung secara manual dengan menggunakan rumus : (Tugas x 15\%) + (Ulangan 1 x 25\%) + (Ulangan 2 x 25\%) + (Ulangan umum x $35 \%$ ).

Sistem Informasi Manajemen Akademik Sekolah yang dirancang dalam penelitian ini, mampu menangani data penerimaan siswa baru, siswa, orang tua siswa, guru, pembagian kelas, mata pelajaran, nilai siswa, absensi siswa serta pembuatan laporan mengenai hasil seleksi siswa baru, data identitas siswa, data alumni, data orang tua siswa, absensi siswa, hasil pembagian kelas, nilai ulangan harian dan tugas, nilai ulangan umum dan ujian, nilai rapor tiap mata pelajaran, nilai rapor tiap siswa dan data statistik siswa.
\end{abstract}

Kata Kunci : sistem informasi, akademik sekolah, asp.net, aplikasi web 


\section{PENDAHULUAN}

Bagian akademik sekolah merupakan bagian yang bertugas untuk mengatur administrasi yang berkaitan dengan siswa, kegiatan belajar mengajar dan nilai siswa dalam upaya pengembangan potensi siswa. Tujuannya untuk mengetahui data siswa, potensi dan kemampuan siswa.

Kesulitan yang sering dihadapi oleh bagian akademik SMPK I Harapan Denpasar dalam mengelola data siswa adalah dalam penyimpanan, pencarian, penambahan dan perubahan data, ini disebabkan oleh masih digunakannya sistem berkas dalam mengelola data siswa. Solusi yang dapat digunakan untuk mengatasi permasalahan ini salah satunya adalah dengan membangun aplikasi sistem informasi manajemen akademik sekolah. Sistem informasi manajemen mampu memberikan banyak kemudahan dalam proses pengolahan data, dimana proses pengolahan data yang biasa dilakukan secara manual dapat diterapkan menjadi sistem komputerisasi yang terintegrasi, dengan demikian data dapat disimpan secara terstruktur sehingga lebih mudah untuk dikelola.

SMPK I Harapan Denpasar sebagai salah satu sekolah swasta dengan status terakreditasi A, memiliki sumber daya baik guru, pegawai maupun siswa yang cukup baik, dan juga didukung dengan fasilitas yang cukup memadai, yaitu sebuah la-boratorium komputer yang terhubung de-ngan jaringan, serta beberapa komputer yang terhubung kedalam LAN (Local Area Net-work) untuk mendukung pekerjaan bagian akademik sekolah. Fasilitas dan sumber daya yang cukup memadai memungkinkan SMPK I Harapan Denpasar untuk menerapkan sis-tem informasi manajemen berbasis web dalam mengelola data yang dimiliki, sehing-ga dapat meningkatkan efektifitas dan efi-siensi kerja pegawai dalam memberikan pelayanan kepada siswa, efektifitas dan efisiensi kerja guru dalam proses belajar mengajar serta memudahkan kontrol kepala sekolah terhadap kinerja guru dan perkem-bangan prestasi siswa.

\section{TINJAUAN PUSTAKA}

\section{Akademik Sekolah}

Bagian akademik sekolah adalah bagian yang membuat dan mengatur arsip arsip yang berkaitan dengan data siswa, guru, rencana kegiatan belajar mengajar dan pencatatan nilai siswa yang kemudian dijadikan bahan pelaporan kepada pihak-pihak yang memerlukan, antara lain : siswa, orang tua / wali siswa, kepala sekolah, yayasan, dan dinas pendidikan setempat. Data yang akan diolah meliputi : Data Guru, Data Siswa, Mata Pelajaran.

\section{Penilaian Kelas}

Penilaian kelas merupakan suatu kegiatan yang dilakukan guru yang berkaitan dengan pengambilan keputusan tentang pencapaian kompetensi dasar setelah mengikuti proses pembelajaran. Data yang diperoleh pendidik selama pembelajaran berlangsung dijaring dan dikumpulkan melalui prosedur dan alat penilaian yang sesuai dengan kompetensi dasar atau indikator yang akan dinilai, dari proses ini diperoleh potret/profil kemampuan peserta didik dalam mencapai sejumlah standar kompetensi dan kompetensi dasar yang dirumuskan dalam Kurikulum Tingkat Satuan Pendidikan masing-masing. Data tersebut diperlukan sebagai informasi yang diandalkan sebagai dasar pengambilan keputusan.

\section{Pelaporan Hasil Penilaian Kelas Bentuk Laporan}

Laporan kemajuan belajar peserta didik dapat disajikan dalam data kuantitatif. Data kuantitatif disajikan dalam angka (skor), misalnya seorang peserta didik mendapat nilai 60 pada mata pelajaran matematika.

\section{Rekap Nilai \\ Rekap nilai merupakan rekap kemajuan belajar peserta didik, yang berisi informasi tentang pencapaian kompetensi peserta didik untuk KD setiap semester. Rekap nilai diperlukan sebagai alat kontrol bagi guru tentang perkembangan hasil belajar peserta didik, sehingga diketahui kapan peserta didik memerlukan remedial.}




\section{Rapor}

Rapor adalah laporan kemajuan belajar peserta didik dalam kurun waktu satu semester. Laporan prestasi mata pelajaran, berisi informasi tentang pencapaian kompetensi yang telah ditetapkan dalam kurikulum tingkat satuan pendidikan. Masingmasing sekolah boleh menetapkan sendiri model rapor yang dikehendaki asalkan menggambarkan pencapaian kompetensi peserta didik pada setiap mata pelajaran yang diperoleh dari ketuntasan kompetensi dasarnya.

Nilai pada rapor merupakan gambaran kemampuan peserta didik, berikut adalah formula untuk menghitung nilai rapor:

Nilai Rapor = Nilai Ulangan harian $(25 \%)+$ Nilai Tugas (25\%) + Nilai Ulangan Umum (50\%)

Gambar 1. Perhitungan Nilai Rapor

Bobot dari masing - masing nilai dapat berubah bergantung dari kebijakan sekolah.

\section{Sistem Informasi Manajemen}

Sistem informasi manajemen merupakan penerapan sistem informasi di dalam organisasi untuk mendukung informasiinformasi yang dibutuhkan oleh semua tingkatan manajemen. (Goerge, 1986). Suatu sistem informasi manajemen juga dapat dikatakan sebagai suatu kumpulan dari interaksi-interaksi sistem - sistem yang menyediakan informasi baik untuk kebutuhan manajerial maupun kebutuhan operasi. Sistem informasi manajemen akan melakukan fungsi - fungsi untuk menyediakan semua informasi yang mempengaruhi semua operasi organisasi. Sistem informasi manajemen juga merupakan kumpulan dari sistem-sistem informasi yang saling men-dukung antara yang satu dengan yang lain-nya.

\section{Merancang Sistem Informasi Manajemen}

Merancang dan membangun suatu sistem informasi harus dilakukan dengan beberapa tahapan yang disusun secara berjenjang sampai sistem tersebut menjadi sistem yang layak dan siap digunakan untuk kemajuan usaha tersebut. (Lucas, 1982). Langkah-langkah yang digunakan da-lam merancang dan membangun sistem informasi adalah sebagai berikut : (1) Penelitian pendahuluan (2) Studi kelayakan (3) Analisis sistem (4) Desain sistem (5) Rancang Bangun (6) Pemrograman (7) Pengetesan (8) Pelatihan (9) Konversi dan instalasi (10) Operasi.

\section{Konsep Database Management System (DBMS)}

Sistem basis data adalah sistem yang terdiri atas kumpulan table / file yang saling berhubungan dalam sebuah program berupa DBMS yang memungkinkan beberapa pemakai atau program lain untuk mengakses dan memanipulasi tabel - tabel tersebut, sehingga dapat disimpulkan pula bahwa sistem basisdata mempunyai beberapa elemen penting, yaitu basisdata sebagai inti dari sistem basisdata, perangkat lunak untuk mengelola basis data, perangkat keras sebagai pendukung operasi pengolahan data, serta manusia mempunyai peran penting dalam sistem tersebut.

MySQL adalah sebuah server database SQL multiuser dan multi-threaded. SQL (Structured Query Language) sendiri adalah bahasa standar yang digunakan untuk mengakses server database. MySQL dibuat oleh suatu badan yang bernama MySQL $A B$ dan telah dipercaya mengelola sistem dengan40 buah database berisi 10.000 tabel dan 500 diantaranya memiliki 7 juta baris (kira - kira 100 gigabyte data). Database ini dibuat untuk keperluan sistem database yang cepat, handal dan mudah digunakan.

\section{Pemrograman Berbasis Web}

Pemrograman berbasis web menggunakan beberapa bahasa yang berbeda yang saling mendukung antara yang satu dengan yang lannya.

\section{Hypertext Markup Language (HTML)}

HTML merupakan bahasa pemrograman fleksibel yang bisa diletakkan atau disisipkan script dari bahasa pemrograman yang lain seperti JAVA, Visual Basic, $C$ dan 
lainnya. Hypertext dalam HTML berarti bahwa kita dapat menuju ke suatu tempat, misalnya Website atau halaman homepage lain, dengan cara memilih suatu link yang biasanya digarisbawahi atau diwakili oleh suatu gambar. Hypertex ini juga mengijinkan kita untuk menuju ke salah satu bagian dalam suatu teks itu sendiri, sedangkan Markup Language menunjukkan suatu fasilitas yang berupa tanda tertentu dalam script HTML di mana kita bisa men-set judul, garis, tabel, gambar dan lain-lainnya, dengan perintah khusus.

\section{Teknologi .NET}

John Connel dalam buku Coding Techniques for Microsoft Visual Basic .NET, mengatakan bahwa alasan dibuatnya .NET adalah memberikan pemakai akses informasi, file atau program, setiap tempat, setiap saat, setiap platform dan setiap device atau perangkat. Pemakai tidak perlu mengetahui dimana informasi berada atau detail bagaimana cara memanggilnya.

\section{Dot NET Framework}

Dot NET Framework adalah lingkungan untuk membangun, deploying / menyebarkan, dan menjalankan services Web dan aplikasi lainnya. Dot NET Framework disusun oleh dua komponen utama, yaitu Common Language Runtime (runtime bahasa umum) dan .NET Framework Class Library (pustaka class .NET Framework)

.NET Framework adalah platform tunggal dimana semua orang dapat mengembangkan aplikasi menggunakan suatu sistem yang mirip dengan JVM (Java Virtual Machine). Berbeda dengan Java, tidak ada penghalang bahasa dengan .NET sehingga aplikasi dapat dikembangkan menggunakan bahasa VB, C++, C\#, J\# dan 20 bahasa pemrograman lainnya yang kompatibel dengan .NET Framework.

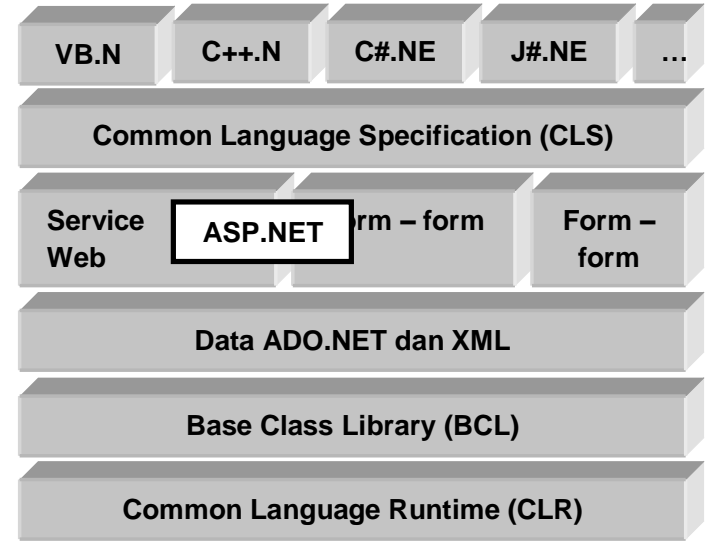

Gambar 2 Dot NET Framework

\section{METODE DAN PERANCANGAN SISTEM}

\section{Perancangan Sistem}

Perancangan sistem dalam penelitian ini dilakukan sesuai langkah-langkah berikut:

\section{Diagram Konteks}

Diagram konteks (context diagram) merupakan pendekatan terstruktur yang bertujuan untuk menggambarkan sistem pertama kali secara garis besar (top level). Diagram konteks terdapat pada Gambar 3.

\section{Normalisasi Tabel}

file yang terdiri dari beberapa grup elemen yang berulang - ulang perlu diorganisasikan kembali. Proses untuk mengorganisasikan file untuk menghilangkan grup elemen yang berulang - ulang ini disebut dengan normalisasi (normalization). Normalisasi juga banyak dilakukan dalam merubah bentuk database dari struktur pohon atau struktur jaringan menjadi struktur hubungan.

Pada penelitian ini proses normalisasi dilakukan untuk mengelompokan data elemen menjadi tabel - tabel yang menunjukkan entitas dan relasinya. Proses normalisasi selalu diuji pada beberapa kondisi, apakah ada kesulitan pada saat menambah, menghapus, mengubah dan membaca pada suatu basisdata, bila ada 
kesulitan, maka relasi tersebut dipecah pada beberapa tabel lagi.

\section{Diagram Alir Data ( DAD )}

Diagram Alir Data (DAD) digunakan untuk menggambarkan aliran data dalam suatu sistem yang akan dikembangkan secara logika tanpa mempertimbangkan lingkungan fisik dimana data tersebut mengalir atau disimpan.

Sketsa rancangan Diagram Alir Data (DAD) dari Sistem Informasi Manajemen Akademik Sekolah bertujuan untuk memperoleh gambaran secara jelas bagaimana sistem tersebut nantinya diterapkan. DAD level

\section{Coding}

Pada tahapan ini dilakukan perancangan dan pembuatan sistem informasi berbasis web yang diinginkan dengan merepresentasikan hasil rancangan pemodelan data yang telah dibuat tersebut ke dalam pemrograman DBMS dan aplikasi DBMA.

\section{Pengujian dan analisis hasil}

Pada tahap ini dilakukan pengujian terhadap sistem ini secara keseluruhan dengan melakukan pengamatan terhadap proses running program aplikasi dan pada

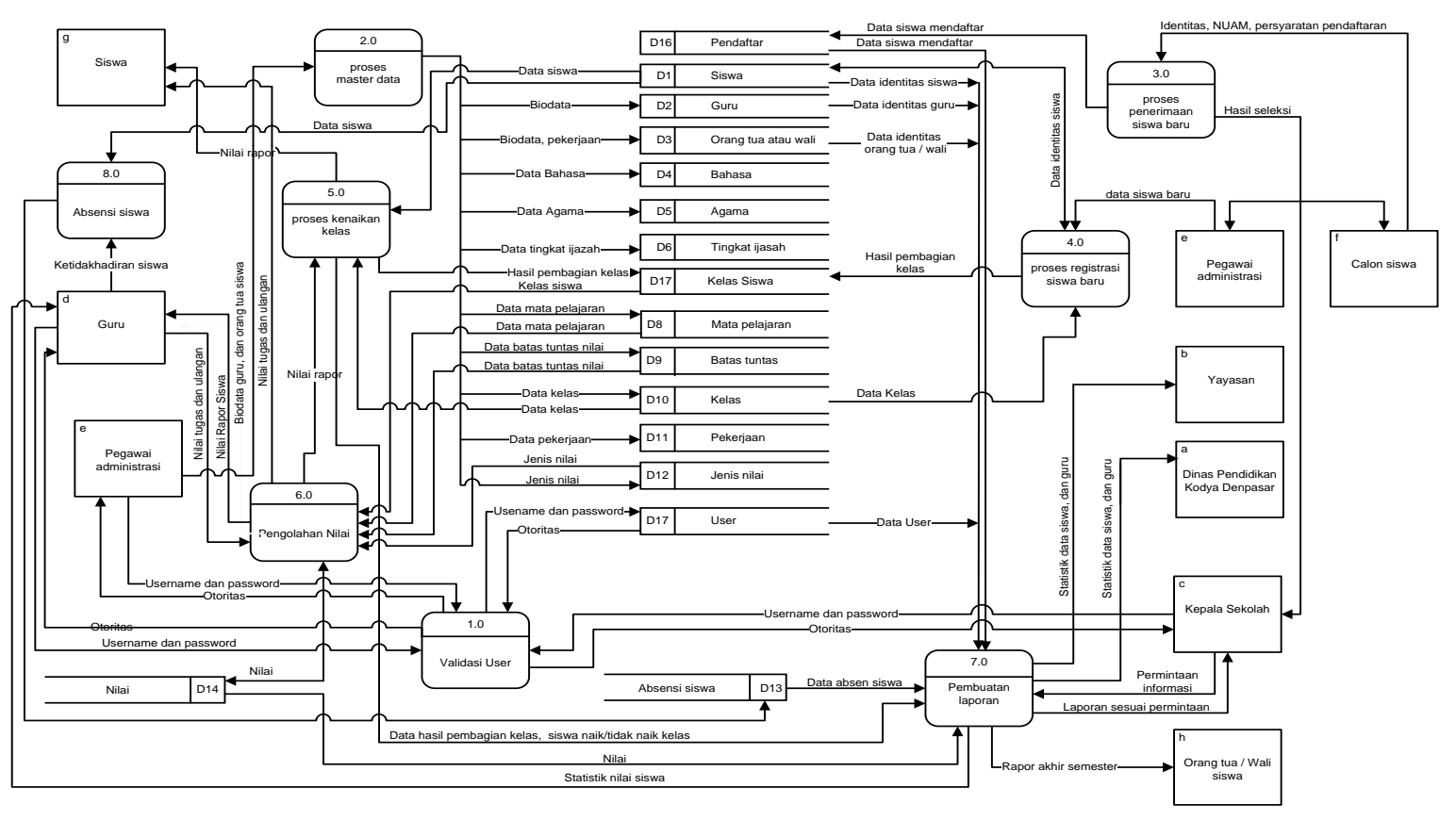

\section{Gambar 3 DAD Sistem Informasi Akademik Sekolah}

\section{Perancangan Antar Muka Sistem}

Desain antarmuka sistem pada penelitian in imenggunakan tools diantaranya Adobe Photoshop 7.0, Macromedia Dreamweaver MX. Selain memperhatikan keindahan tampilan, pada tahap ini juga diperhatikan kesesuaian kolom-kolom yang dibutuhkandengan field yang ada pada table database, sehingga semua data yang di masukkan melalui antarmuka sistem dapat tertampung di database. pengaturan hak akses (otoritas) bagi seorang user maupun admin. Pengujian terhadap sistem ini pada akhirnya bertujuan untuk mengetahui seberapa jauh tingkat keberhasilan yang dicapai sesuai dengan tujuan yang telah dibuat. 


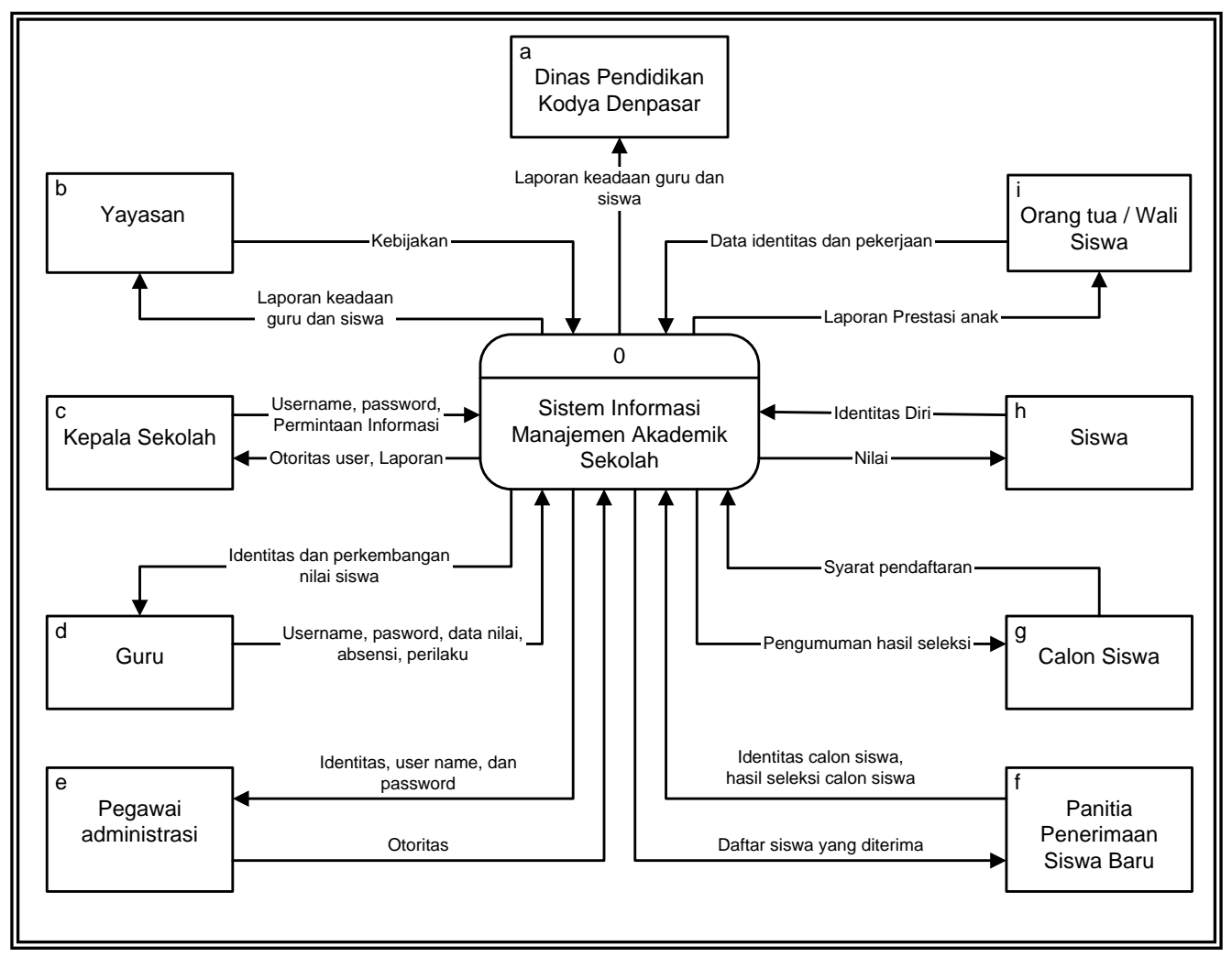

Gambar 4. Diagram Konteks

\section{PENGUJIAN DAN ANALISA HASIL}

\section{Pengujian Sistem.}

Sistem ini akan diinstal pada sebuah computer server yang dikelola oleh seorang admin, system dapat diakses oleh komputer lain yang terdapat pada ruang administrasi dan ruang guru, dimana semua computer ini terhubung ke dalam Local Area Network $(L A N)$.

Pengujian sistem diperlukan untuk mengetahui apakah system sudah berfungsi dengan baik dalam melakukan manajemen data akademik sekolah, pengujian sistem akan dilakukan dengan tahapan-tahapan sebagai berikut :

\section{Instalasi requirement sistem.}

Instalasi kebutuhan -kebutuhan (requirement) sistem dilakukan pada sebuah komputer yang akan digunakan sebagai server untuk uji coba sistem, sehingga seluruh fungsi sistem dapat bekerja dengan baik. Kebutuhan perangkat lunak dari Sistem Informasi Manajemen Akademik Sekolah ini adalah sebagai berikut : (1) Internet Information Ser-vices 5.1 (2) Microsoft.Net (3) Framework 2.0 (4) MySQL Connector / NET 5.0.8.1 (5) SQL Enterprise 5.17 (6) Database MySQL Server 5.0 Crystal Report.

\section{Uji Coba Instalasi Sistem.}

Proses instalasi Sistem Informasi Manajemen Akademik Sekolah dilakukan dengan menyalin semua halaman web ke dalam suatu directory, kemudian membuat suatu virtual directory pada IIS yang diarahkan ke directory tempat menyimpan halaman web, kemudian dilakukan persiapan

database dengan cara membuat database baru pada MySQL server melalui SQLyog dengan nama db_simaks, kemudian menyalin database system ke database yang baru dibuat. Uji coba ini bertujuan untuk mengetahui apakah sistem yang telah dibuat dapat berfungsi dengan baik seperti pada 
komputer yang telah digunakan untuk membangun sistem.

\section{Uji Coba Antarmuka Sistem}

Tahap pengujian berikutnya adalah uji coba antarmuka sistem. Pengujian ini bertujuan untuk menguji apakah semua form-form yang ada dalam system sudah berfungsi dengan benar agar kesalahan yang terjadi dapat seminimal mungkin. Pengujian antarmuka system juga termasuk pengujian terhadap :

\section{Input Data}

Proses Input data dilakukan oleh pengguna (user). Input data dimulai dengan melakukan input data master yang merupakan sumber data dari suatu transaksi / proses pengolahan data yang akan dilakukan selanjutnya, kemudian akan dilakukan uji coba input data personal dan nilai siswa.

\section{Edit dan Query Data}

Uji coba Edit data bertujuan untuk melakukan perubahan terhadap data yang terdapat di dalam database.Query dataadalah proses pencarian informasi yang terdapat dalam database. Query dapat disertai dengan beberapa parameter sesuai dengan keperluan user.

\section{Tampilan Informasi}

Semua pengguna sistem, baik administrator maupun user dapat melakukan pengujian tampilan laporan dari sistem ini sesuai dengan informasi yang dibutuhkan oleh user. Informasi yang dihasilkan ditampilkan melalui report data.

\section{PENGUJIAN DAN ANALISA HASIL Pengujian Sistem.}

Sistem ini akan diinstal pada sebuah computer server yang dikelola oleh seorang admin, system dapat diakses oleh komputer lain yang terdapat pada ruang administrasi dan ruang guru, dimana semua computer ini terhubung ke dalam Local Area Network $(L A N)$

Pengujian sistem diperlukan untuk mengetahui apakah system sudah berfungsi dengan baik dalam melakukan manajemen data akademik sekolah, pengujian sistem akan dilakukan dengan tahapan-tahapan sebagai berikut :

\section{Instalasi requirement sistem.}

Instalasi kebutuhan - kebutuhan (requirement) sistem dilakukan pada sebuah komputer yang akan digunakan sebagai server untuk uji coba sistem, sehingga seluruh fungsi sistem dapat bekerja dengan baik. Kebutuhan perangkat lunak dari Sistem Informasi Ma-najemen Akademik Sekolah ini adalah seba-gai berikut : (1) Internet Information Services 5.1 (2) Microsoft .Net (3) Framework 2.0 (4) MySQL Connector / NET 5.0.8.1SQL Enterprise 5.17 (Database MySQL Server 5.0 (5) Crystal Report.

\section{Uji Coba Instalasi Sistem.}

Proses instalasi Sistem Informasi Manajemen Akademik Sekolah dilakukan dengan menyalin semua halaman web kedalam suatu directory, kemudian membuat suatu virtual directory pada IIS yang diarahkan ke directory tempat menyimpan halaman web, kemudian dilakukan persiapan database dengan cara membuat database baru pada MySQL server melalui SQLyog dengan nama db_simaks, kemudian menyalin database system ke database yang baru dibuat. Uji coba ini bertujuan untuk mengetahui apakah sistem yang telah dibuat dapat berfungsi dengan baik seperti pada komputer yang telah digunakan untuk membangun sistem.

\section{Uji Coba Antarmuka Sistem}

Tahap pengujian berikutnya adalah uji coba antarmuka sistem. Pengujian ini bertujuan untuk menguji apakah semua formform yang ada dalam system sudah berfungsi dengan benar agar kesalahan yang terjadi dapat seminimal mungkin. Pengujian antarmuka system juga termasuk pengujian terhadap :

\section{Input Data}

Proses Input data dilakukan oleh pengguna (user). Input data dimulai dengan melakukan input data master yang merupakan 
sumber data dari suatu transaksi/proses pengolahan data yang akan dilakukan selanjutnya, kemudian akan dilakukan uji coba input data personal dan nilai siswa.

\section{Edit dan Query Data}

Uji coba Edit data bertujuan untuk melakukan perubahan terhadap data yang terdapat di dalam database.Query dataadalah proses pencarian informasi yang terdapat dalam database. Query dapat disertai dengan beberapa parameter sesuai dengan keperluan user.

\section{Tampilan Informasi}

Semua pengguna sistem, baik administrator maupun user dapat melakukan pengujian tampilan laporan dari sistem ini sesuai dengan informasi yang dibutuhkan oleh user.Informasi yang dihasilkan ditampilkan melalui report data.

\section{Analisa Hasil}

Analisis hasil yang dilakukan adalah analisa terhadap hasil perhitungan nila irapor, pertumbuhan data, analisis kekurangan dan kelebihan sistem serta analisa mengenai kelayakan system untuk diimplementasikan secara nyata.

\section{Analisa Hasil Perhitungan Nilai Rapor} Pengujian ini berfungsi untuk mengetahui apakah rumus atau formula yang digunakan sudah berhasil diterapkan dengan benar dalam logika program, sehingga menghasilkan perhitungan yang benar. Untuk mengetahui kebenaran hasil perhitungan nilai rapor maka akan dilakukan pengujian dengan memasukkan beberapa nilai siswa kelas VIIA sebagai berikut :

1. Nilai Tugas, bobot nilai $15 \%$

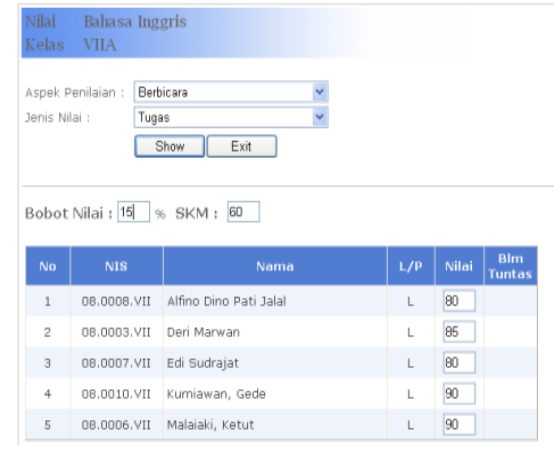

Gambar 5. Nilai Tugas Siswa

2. Nilai Ulangan 1 , bobot nilai $25 \%$

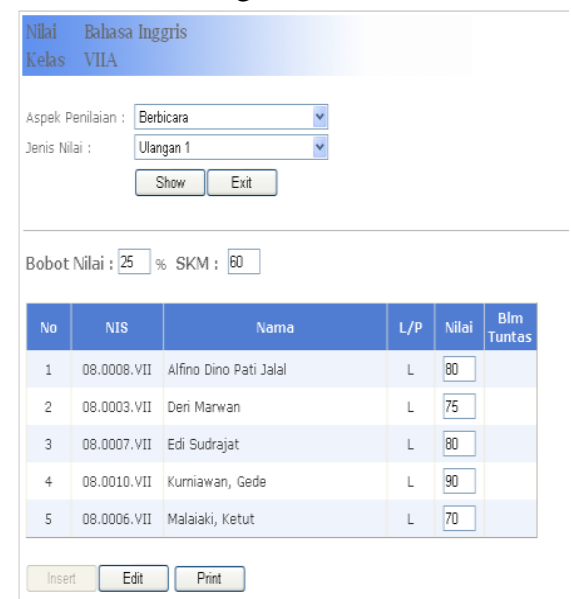

Gambar 6. Nilai Ulangan 1

3. Nilai Ulangan 2, bobot nilai $25 \%$

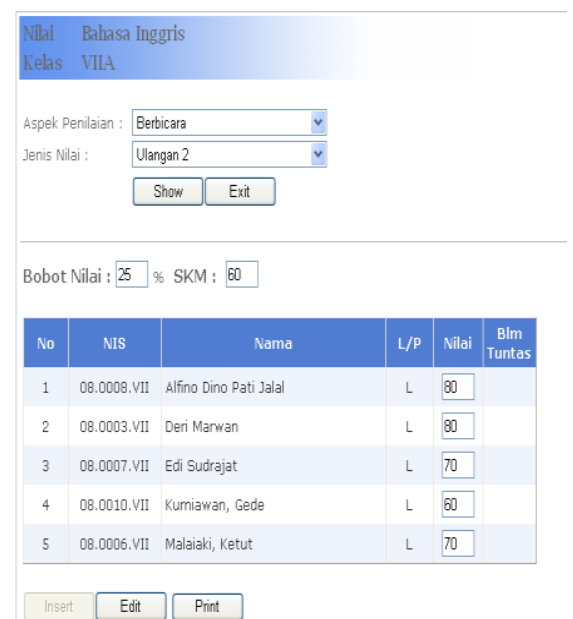

Gambar 7. Nilai Ulangan 2 
4. Nilai Ulangan Umum, bobot nilai $35 \%$

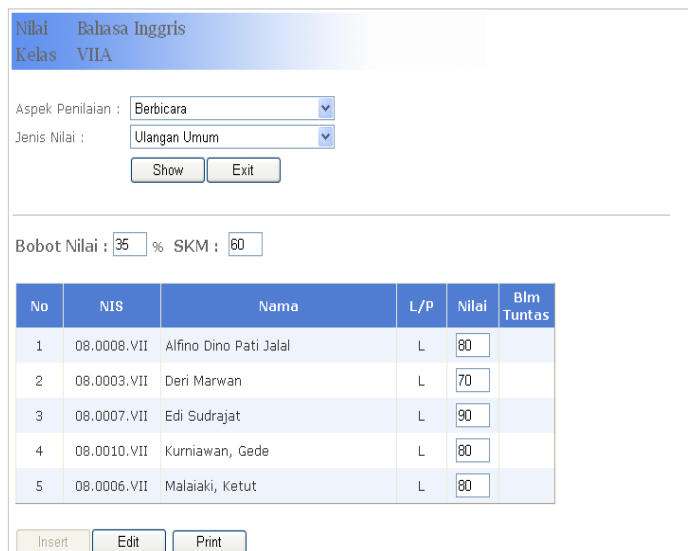

Gambar 8. Nilai Ulangan Umum

5. Hasil perhiungan nilai rapor yang dihasilkan oleh system adalah sebagai berikut :

\begin{tabular}{|c|c|c|c|c|c|}
\hline \multicolumn{6}{|c|}{ DAFTAR NILAI RAPOR SISWA } \\
\hline \multirow{2}{*}{$\begin{array}{l}\text { Kelas } \\
\text { Th Ajaran } \\
\text { Semester } \\
\begin{array}{|l|}\text { Noo } \\
\end{array}\end{array}$} & $\begin{array}{l}: \text { VIIA } \\
: 2008 / 2009 \\
: 1\end{array}$ & & $\begin{array}{l}\text { Mata Pelajaran } \\
\text { Aspek Penilaian }\end{array}$ & \multicolumn{2}{|c|}{$\begin{array}{l}\text { Bahasa Inggris } \\
\text { Berbicara }\end{array}$} \\
\hline & Nis & Nama & & SKI & Nilai \\
\hline 1 & $08.0008 \mathrm{VII}$ & Alfino Dino Pati Jalal & & 60 & 80.00 \\
\hline 2 & 08.0003.VII & Deri Marwan & & 60 & 76.00 \\
\hline 3 & $08.0007 \mathrm{VII}$ & Edi Sudrajat & & 60 & 81.00 \\
\hline 4 & $08.0010 \mathrm{VII}$ & Kurniawan, Gede & & 60 & 79.00 \\
\hline 5 & $08.0006 \mathrm{VII}$ & Malaiaki, Ketut & & 60 & 76.50 \\
\hline
\end{tabular}

Gambar 9. Hasil Perhitungan Nilai Rapor

Jika perhitungan nilai rapor di atas dihitung secara manual dengan menggunakan rumus :

(Tugas x 15\%) + (Ulangan 1 x 25\%) + (Ulangan $2 \times 25 \%$ ) + (Ulangan umum $x$ $35 \%$ )

Maka hasil nilai rapor yang didapat :

Tabel 1. Hasil Perhitungan Manual Nilai Rapor

\begin{tabular}{|l|l|l|}
\hline No & \multicolumn{1}{|c|}{ Nama } & $\begin{array}{c}\text { Nilai } \\
\text { Rapor }\end{array}$ \\
\hline 1 & Alfino Dino Pati Jalal & 80.00 \\
\hline 2 & Deri Marwan & 76.00 \\
\hline 3 & Edi Sudrajat & 81.00 \\
\hline 4 & KuniawanGede & 79.00 \\
\hline 5 & MalaiakiKetut & 76.50 \\
\hline
\end{tabular}

Analisa diatas memperlihatkan bahwa hasil perhitungan secara manual dan output yang dihasilkan oleh system menunjukkan hasil yang sama, ini menunjukkan bahwa rumus atau formula yang digunakan untuk menghitung nilai rapor sudah dapat diterapkan dengan benar dalam logika program.

\section{SIMPULAN}

Sistem Informasi Manajemen Akademik Sekolah merupakan sistem yang dirancang dan dibangun dengan teknologi berbasis web dengan menggunakan database relasional yang dibangun dalam MySql Server dan bahasa pemrograman C\# yang digunakan dalam ASP.NET, sehingga sistem dapat diakses secara bersamaan oleh beberapa pengguna melalui jaringan lokal sekolah, dimana setiap pengguna dalam system ini memiliki otoritas yang berbeda-beda yang diatur sesuai dengan group user sehingga sistem dapat membatasi pengguna untuk mengakses halaman tertentu.

Sistem ini memberikan banyak manfaat bagi sekolah dalam hal efisiensi kerja guru dan pegawai, sistem ini mampu melakukan perhitungan terhadap nilai siswa secara otomatis. Sistem Informasi Manajemen Akademik Sekolah mampu menangani data penerimaan siswa baru, siswa, orang tua siswa, guru, pembagian kelas, mata pelajaran, nila isiswa, absensi siswa serta pembuatan laporan mengenai hasil seleksi siswa baru, data identitas siswa, data alumni, data orang tua siswa, absensi siswa, hasil pembagian kelas, nilai ulangan harian dan tugas, nilai ulangan umum dan ujian, nilai rapor tiap mata pelajaran, nilai rapor tiap siswa dan data statistik siswa.

\section{DAFTAR PUSTAKA}

[1] Departemen Pendidikan Nasional, 2007. Model Penilaian Kelas

Kurikulum Tingkat Satuan Pendidikan. Jakarta : CV Timur Putra Mandiri

[2] Hartono, Jogiyanto.1999. Analisis Dan Design Sistem Informasi. Yogyakarta: ANDI.

[3] Mulyasa, E. 2002. Manajemen Berbasis Sekolah. Bandung : PT RemajaRosdakarya. 
73 Jurnal Teknologi Informasi dan Komputer, Volume1, Nomor 1, Januari 2015

[4] Mayo, Joseph. 2002. C\# Unleashed.

USA :Sams Publishing.

[5] Olsen, andy. 2006. Total Training

For Microsoft ASP.NET 2.0

Building Web Application Set 1 And

Set 2. Total Training Inc.

[6] Budiharto, WidododanSukmadi, Dodi

Yogi. 2004. Aplikasi e-Commerce

Menggunakan Visual C\#.NET.

Yogyakarta : ANDI.

[7] Kadir, Abdul. 2002. Penuntun

Praktis Belajar SQL. Yogyakarta :

ANDI.

[8] Online Documentation,

http://www.mysql.com, 2008

[9] Online Documentation,

http://www.asp.net, 2008

[10] Online Documentation,

http://www.javascript.com, 2008 